\title{
Changes in glutamine, glutamate and alanine concentrations after Vaquejada and 3-barrel simulation test on horses
}

\author{
Alterações nas concentrações de glutamina, glutamato e alanina após teste \\ de simulação de Vaquejada e de 3 tambores em cavalos
}

Carolina Jones Ferreira Lima Silva (D) ${ }^{1 *}$, Monica Miranda Hunka (D) 1 , Luzilene Araújo Souza (D) , Clarisse Simões Coelho (D) 2,3 Fabiana Oliveira Costa (D)1, Helena Emília Cavalcanti da Costa Cordeiro Manso (D) , Hélio Cordeiro Manso Filho (D) ${ }^{1}$

\footnotetext{
${ }^{1}$ Universidade Federal Rural de Pernambuco (UFRPE), Recife, PE, Brazil

2 Universidade Federal da Bahia (UFBA), Salvador, BA, Brazil

${ }^{3}$ Faculty of Veterinary Medicine, Universidade Lusofona de Humanidades e Tecnologias de Lisboa (ULHT), Lisboa, Portugal
}

\begin{abstract}
The aim of this study was to determine the plasmatic glutamine (Gln), glutamate (Glu), and alanine (Ala) concentrations in athlete horses subjected to field simulations of Vaquejada and 3-barrel racing. Twentythree animals were used, trained and conditioned, and grouped according to their activity and function as follows: Vaquejada pull horses (G-PUX; $\mathrm{n}=12$ ), Vaquejada helper horses (G-AUX; $n=6$ ), and -barrel horses (G-3TB; $n=5)$. All were from the same training center with the same food management, receiving commercial concentrate divided equally into two meals, water, mineralized salt, and fresh grass ad libitum. Blood
\end{abstract}

samples were collected after overnight fasting by jugular venipuncture with vacuum collection tubes containing heparin, and were immediately refrigerated. Samples were collected for each group at different times; G-PUX: rest (T0), immediately after three races (T1), and 15, 30, and 240 min after the third race; G-AUX: rest (TO), immediately after six races (T1), and 15, 30, and $240 \mathrm{~min}$ after the sixth race; G-3TB: rest (T0), immediately after two races (T1), and 15, 30, and $240 \mathrm{~min}$ after the last race. After $15 \mathrm{~min}$, the animals had free access to water, mineralized salt, and grass. The heparinized plasma was extracted, acidified, and neutralized as described in the 
literature, and was later stored and frozen at $20{ }^{\circ} \mathrm{C}$ until analysis. The concentration levels of the amino acids were enzymatically determined using a semiautomatic spectrophotometric machine. The data obtained were analyzed using analysis of variance and the Tukey test. The results showed that all the three groups had plasma concentration changes for Ala ( $p<0.05$ ), but not for Glu ( $p>0.05$ ). In addition, it was observed that only the G-AUX group showed significant changes in Gln concentration, which was high between T-1 and T-240 ( $p$ $<0.05)$. The difference observed between the measured plasma levels of Gln, Glu and Ala are due to the intensity and duration of each physical activity performed in the experimental groups.

Keywords: Amino acid metabolism. Skeletal muscle. Catabolism. Exercise.

\section{Resumo}

O objetivo deste estudo foi determinar as concentrações plasmáticas de glutamina (G/n), glutamato (G/u) e alanina (Ala) em cavalos atletas submetidos a simulações de campo de Vaquejada e corridas de 3 tambores. Vinte e três animais foram utilizados, treinados e condicionados, agrupados de acordo com sua atividade e função: cavalos puxadores para Vaquejada (G-PUX; $n$ = 12), cavalos auxiliares para Vaquejada (G-AUX $n=6)$ e cavalos de 3 tambores (G-3TB; $n=5$ ). Todos eram do mesmo centro de treinamento com o mesmo manejo alimentar, recebendo concentrado comercial dividido igualmente em duas refeições: água, sal mineralizado e capim fresco ad libitum. As amostras de sangue foram coletadas após jejum noturno por punção venosa jugular, com tubos de coleta a vácuo contendo heparina, e foram imediatamente refrigeradas. As amostras foram coletadas para cada grupo em momentos diferentes; G-PUX: repouso (TO), imediatamente após três corridas (T1) e 15, 30 e 240 min após a terceira corrida; G-AUX: repouso (T0), imediatamente após seis corridas (T1) e 15, 30 e 240 min após a sexta corrida; G-3TB: descanso (T0), imediatamente após duas corridas (T1) e 15, 30 e 240 min após a última corrida. Após 15 minutos, os animais tiveram livre acesso à água, sal mineralizado e pasto. O plasma heparinizado foi extraído, acidificado e neutralizado como descrito na literatura e posteriormente armazenado e congelado a $20{ }^{\circ} \mathrm{C}$ até análise. Os níveis de concentração dos aminoácidos foram determinados enzimaticamente usando equipamento espectrofotométrico semiautomático. Os dados obtidos foram analisados por meio da análise de variância e teste de Tukey. Os resultados mostraram que os três grupos apresentaram alterações na concentração plasmática de Ala ( $p<0,05)$, mas não de Glu ( $p>0,05)$. Além disso, observou-se que apenas o grupo G-AUX apresentou alterações significativas na concentração de Gln, alta entre T-1 e T-240 ( $p<0,05)$. As diferenças observadas entre níveis plasmáticos da Gln, Glu e Ala mensuarados se devem à intensidade e duração de cada atividade física executada nos grupos experimentais.

Palavras-chave: Metabolismo de aminoácido. Músculo esquelético. Catabolismo. Exercício.

\section{Introduction}

Horses have large skeletal muscle mass that is developed during natural and artificial selection to increase power, speed, and stamina. These skeletal muscles work as an important reserve of protein and amino acids, which are released during diseases and health activities, such as exercise. Skeletal muscle catabolism under these conditions produces a large release of amino acids that can be used during gluconeogenesis in the liver, in combination with lactate, or as a nutrient for the enterocytes and immune cells. Gluconeogenesis is an important pathway for substrate delivery during synthesis of glucose, which may return to the skeletal muscles and other tissues (Lewis et al., 2010). This process may support rapid recovery of glucose concentrations in the horse blood and may reduce the time to fatigue.

Exercise, in a quantitative way, contributes significantly to protein degradation and synthesis, while protein synthesis may not reach the necessary levels at the same speed as it is consumed; thus, resulting in a negative balance of some amino acids (Van Hall et al., 1999). During exercise, the skeletal muscles intensely consume branched chain amino acids (valine, leucine, and isoleucine), and other amino acids, such as glutamine (Gln) and alanine (Ala), are produced and released 
in the bloodstream. These two amino acids can represent up to $80 \%$ of all the released amino acids and are important substrates for gluconeogenesis, energetic metabolites for the small and large intestines, and for the immune cells (Van Hall et al., 1999). Any major disruption of this process may reduce the availability of these amino acids for the recovery process after exercise, compromising the welfare of athletic horses.

Different equine sports, both high and low intensity, produce modifications on the amino acid concentrations in the blood and skeletal muscles (Wolfe et al., 1984; Hanzawa et al., 1992; Wanderley et al., 2010). However, little information is available regarding the changes in Gln, glutamate (Glu), and Ala concentrations after Vaquejada and 3-barrel races. Hence, to test the hypothesis that Gln, Glu, and Ala concentrations decrease after Vaquejada and 3-barrels races, we developed a study that aimed to determine Gln, Glu, and Ala concentrations in horses subjected to field simulations of Vaquejada and 3-barrel races. This information will be used to decide the right feed and training managements for these athletic horses.

\section{Material and methods}

The present study was authorized by the Ethics and Animal Experimentation Committee of the Federal Rural University of Pernambuco through the licenses 105/2015 and 090/2016.

\section{Animals and breeding system}

Twenty-three Quarter horses (females: 7; males: 16) (age: 6.6 years; body weight: $470 \mathrm{~kg}$ ) were used. In addition, these horses were grouped according to their sports and function: Vaquejada pull horses (G-PUX; $n=12$ ), Vaquejada helper horses (G-AUX; $n=6)$, and 3-barrel horses (G-3TB; $n=5)$. They were well trained and conditioned for at least 6 months before this evaluation, were placed in the same training center ( $\left.8^{\circ} 19^{\prime} 39^{\prime \prime} \mathrm{S}, 35^{\circ} 4^{\prime} 20^{\prime \prime} \mathrm{W}\right)$, and received the same commercial concentrate $(4.8$ $\mathrm{kg} /$ horse/day; $14 \%$ crude protein, $7.5 \%$ fat, $12 \%$ crude fiber, and $3.85 \% \mathrm{Mcal} / \mathrm{kg}$ digestible energy) divided equally in two meals. Water, mineralized salt, and fresh grass (Pennisetum purpureum and Panicum maximum cv. Massai) were provided ad libitum. At the training center, to attend to good welfare practices, horses could have eye, olfaction, and physical contact with other horses, and could stay in the paddocks with food (grass), water, and shadow for a few hours a day (Coelho et al., 2018; Filho et al., 2018).

\section{Field race simulation test, collection and analysis of blood samples}

Each group was subjected to a field simulation test, following the protocols described for Vaquejada (Santiago et al., 2014; Hunka et al., 2017) and 3-barrel races (Souza et al., 2018).

Horses' blood samples were collected after overnight fasting by jugular venipuncture in vacuum collecting tubes containing heparin, and were immediately refrigerated. Samples were collected for each group at different times; Vaquejada pull horses (G-PUX): rest (TO), immediately after three races $(T 1)$, and 15,30 , and 240 min after the third race; Vaquejada helper horses (G-AUX): rest (TO), immediately after six races (T1), and 15, 30, and 240 min after the sixth race; 3-barrel horses (G-3TB): rest (T0), immediately after two races (T1), and 15, 30 , and 240 min after the last race.

During the recuperation period, after $15 \mathrm{~min}$, the animals had free access to water, mineralized salt, and grass. The collected samples were refrigerated and centrifuged at $1500 \times \mathrm{g}$ for $10 \mathrm{~min}$. The heparinized plasma was extracted, acidified, and neutralized (Manso Filho et al., 2008); subsequently, these samples were stored and frozen to $20^{\circ} \mathrm{C}$ until analysis. The concentration levels of $\mathrm{Gln}, \mathrm{Glu}$, and Ala were determined using a semiautomatic spectrophotometric machine (Peake et al., 2014).

\section{Statistical analysis}

The obtained data were analyzed by analysis of variance using the factor for repeated measurements and by the Tukey test, when necessary. The value of $p$ was established as $5 \%$. The SigmaPlot 13.0 for Windows ${ }^{\circledR}$ (Systat Software, Inc.) software was used for the statistical analysis and the results were expressed in media +/- standard error. 


\section{Results}

The results showed that all the three groups had changes in the plasmatic concentrations of Ala ( $p<0.05$ ), but not of Glu ( $p>0.05)$ during each field simulation test. In addition, it was observed that only the G-AUX group had significant changes in Gln concentration, which was elevated between T-1 and T-240 ( $p<0.05)$ (Table 1). The concentration of Ala significantly increased after exercise in all the groups, but the period of high concentration was different between the groups. Ala concentration remained elevated until $240 \mathrm{~min}$ after exercise in the G-PUX and G-AUX groups, unlike the G-3TB group, which had a similar plasma concentration of Ala at T0 and T-240 ( $p>0.05)$. The highest concentration of Ala occurred at T30 in the G-PUX and G-3TB groups and at T1 in the G-AUX group. In all the three groups, the lowest Ala concentration was observed at TO.

Table 1 - Concentrations of glutamine (Gln), glutamate (Glu), and alanine (Ala) in the plasma of horses subjected to different field simulation tests of short duration and high intensity

\begin{tabular}{|c|c|c|c|c|c|}
\hline \multirow{2}{*}{$\begin{array}{l}\text { Type of } \\
\text { exercise }\end{array}$} & \multicolumn{5}{|c|}{ Phases of blood collection } \\
\hline & TO & T1 & T15 & T30 & T240 \\
\hline \multicolumn{6}{|l|}{ G-PUX } \\
\hline $\mathrm{Gln}, \mu \mathrm{mol} / \mathrm{L}$ & $358.0 \pm 43.4$ & $457.0 \pm 106.0$ & $371.0 \pm 44.0$ & $355.0 \pm 45.9$ & $432.0 \pm 47.4$ \\
\hline Glu, $\mu \mathrm{mol} / \mathrm{L}$ & $90.7 \pm 8.0$ & $87.7 \pm 8.1$ & $92.0 \pm 9.3$ & $97.4 \pm 6.9$ & $90.8 \pm 7.2$ \\
\hline Ala, $\mu \mathrm{mol} / \mathrm{L}$ & $109.0 \pm 20.9^{B}$ & $228.0 \pm 21.7^{\mathrm{A}}$ & $267.0 \pm 30.8^{A}$ & $293.0 \pm 32.5^{\mathrm{A}}$ & $211.0 \pm 17.4^{\mathrm{A}}$ \\
\hline \multicolumn{6}{|l|}{ G-AUX } \\
\hline $\mathrm{Gln}, \mu \mathrm{mol} / \mathrm{L}$ & $389.0 \pm 43.6^{\mathrm{B}}$ & $437.0 \pm 32.2^{\mathrm{AB}}$ & $450.0 \pm 3.1^{A B}$ & $432.0 \pm 4.1 \mathrm{AB}$ & $554.0 \pm 23.8^{A}$ \\
\hline Glu, $\mu \mathrm{mol} / \mathrm{L}$ & $77.8 \pm 16.9$ & $70.4 \pm 9.5$ & $59.7 \pm 0.1$ & $50.2 \pm 2.7$ & $78.0 \pm 5.4$ \\
\hline Ala, $\mu \mathrm{mol} / \mathrm{L}$ & $175.0 \pm 27.6^{\mathrm{B}}$ & $292.0 \pm 11.1^{\mathrm{A}}$ & $241.0 \pm 26.4^{\mathrm{AB}}$ & $216.0 \pm 46.5^{\mathrm{AB}}$ & $302.0 \pm 5.8^{\mathrm{A}}$ \\
\hline \multicolumn{6}{|l|}{ G-3TB } \\
\hline $\mathrm{Gln}, \mu \mathrm{mol} / \mathrm{L}$ & $324.0 \pm 26.5$ & $293.0 \pm 20$ & $317.0 \pm 26.1$ & $365.0 \pm 25.2$ & $299.0 \pm 24.0$ \\
\hline Glu, $\mu \mathrm{mol} / \mathrm{L}$ & $71.19 \pm 15.5$ & $68.38 \pm 13.7$ & $78.65 \pm 7.5$ & $66.46 \pm 9.4$ & $71.59 \pm 5.1$ \\
\hline Ala, $\mu \mathrm{mol} / \mathrm{L}$ & $153.0 \pm 7.1^{c}$ & $198.0 \pm 16.1^{\mathrm{BC}}$ & $263.0 \pm 23.8^{\mathrm{AB}}$ & $280.0 \pm 21.0^{A}$ & $165.0 \pm 13.9 c$ \\
\hline
\end{tabular}

Note: Different letters in the same line indicate $p<0.05$ by Tukey test; T0: rest/fasting period; T1: immediately after the last race; T15: 15 min after the last race; T30: $30 \mathrm{~min}$ after the last race; T240: $240 \mathrm{~min}$ after the last race. G-PUX, Vaquejada pull horses; G-AUX, Vaquejada helper horses; G-3TB, 3-barrel horses.

\section{Discussion}

The results of this study showed that the plasmatic concentrations of Ala and Gln changed significantly between all the three groups of horses, and may reflect the duration of exercise. The exercise duration for G-AUX is higher, about 6 minutes, due to a greater number of races during training, different from the G-PUX and G-3TB groups, where the exercise duration is 2.5 and 1.5 minutes respectively. The findings for the G-PUX and G-3TB groups were similar to those described for intense exercises $>80 \% \mathrm{VO}_{2} \max$, where a high release of Ala was noted (Lewis et al., 2010; Peake et al., 2014; Santiago et al., 2014). However, changes in Gln concentration in the G-AUX group were not expected because previous research had not reported changes in Gln concentration in Vaquejada helper horses (Santiago et al., 2014). An increase in the plasmatic concentration of Gln was frequent in endurance - or resistance - type exercise (Wanderley et al., 2010). 
Different studies have indicated that the concentrations of Ala and Gln can show similar modification patterns in the plasma after exercise, but these changes depend on the type of exercise (Peake et al., 2014). Metabolomic studies performed on human athletes for identification of amino acid-like biomarkers associated with exercise have demonstrated that after medium intensity exercise ( $<65 \% \mathrm{VO}_{2} \max$ ) concentration of Ala and Gln increased, similar to that as noted in the G-AUX group in this study, explaining what happens in the muscular tissue (Lewis et al., 2010).

In this study, the concentration of Ala changed in all three groups, although the exercises were different in duration, but similar in intensity. The maximum heart rate during exercise for pulled, auxiliary and 3-barrel horses is around 209, 196 and 202 bpm, respectively (Hunka et al., 2017; Souza et al., 2018), showing that these equine sports produce similar high intensity exercise. However, the current results indicate that despite having similar intensity, the way each exercise is performed promotes a different energy expenditure, which can be perceived in the 3-barrel race, which requires a greater demand for strength than in Vaquejada. The highest variation occurred in the G-PUX group, where the concentration level of Ala was elevated about one and a half times of the medium intensity exercise value, similar to that of previous studies (Santiago et at., 2014). In addition, results of this study were similar to those of other studies on athletic horses in different equestrian sports, with an elevation of Ala levels next to maximum effort or right after exercise (Trottier et al., 2002; Bergero et al., 2005).

Recently, it was reported that Ala could be a better biomarker of intense and moderate exercise than Gln (Peake et al., 2014). An increase in Ala concentrations in the blood stream shows its levels of synthesis and release, resulting in skeletal muscular metabolism (Van Hall et al., 1999). Data based on the hypothesis that a high release of Ala by the skeletal musculature during exercise is associated with some degree of hypoxia, which occurs during intense exercise, have been reported (Van Hall et al., 1999). Furthermore, Ala acts in the metabolic reload of the glucose levels after exercise (Wahren et al., 1973).
In addition, athletic horses subjected to training show an increase in Ala concentration associated with the resynthesis of Ala during exercise (Westermann et al., 2011). Another possible reason for the increase in blood Ala concentration during exercise in human and equestrian athletes is the increase in nitrogen transfer from the branched chain amino acids for the synthesis of Ala (Wolfe et al., 1984; Pösö et al., 1991; Hood and Terjung, 1994). This increase, in addition to the provision of energy, can be connected to the acid-base equilibrium, since ammonia and lactate are used for the synthesis of GIn and Ala, that are produced during muscular work (Beaunoyer et al., 1991; Peake et al., 2014). This process is important for the athletic horse because it increases the muscle production and the release of Ala, which can be delivered to the gluconeogenesis pathway and reduce the increase in nitrogen metabolites after exercise, and may reduce the time to fatigue.

There are some conflicts between results regarding changes in Gln concentration in athletic horses after intense exercise. In a previous study, the Gln concentration in helper horses reduced immediately after exercise but returned to pretest values after 15 minutes of recovery (Santiago et al., 2014). This kind of variation of Gln concentration in horses was not noted in this study, where Gln concentrations were elevated after exercise for approximately four hours, reflecting the continued Gln production by the skeletal muscle and/or reduced consumption by the tissues that used this amino acid, such as the intestines and white blood cells.

The skeletal musculature presents a total volume of Gln synthase and it is known as the largest GIn producer, followed by the lungs and the liver (Manso Filho et al., 2008). Once GIn enters the blood stream, it reaches the principal organs of consumption; this characteristic provides an increased Gln synthesis by the skeletal muscle during the periods of high energetic demand, such as exercise. The G-AUX group presented a higher concentration of Gln during the recovery period. The ability to perform mostly aerobic activity can be an important factor for the observed results, since there is a higher mitochondrial activity in the muscular tissue, which benefits Gln synthesis. 
In addition, Gln is considered as the principal source of energy for oxidative metabolism of the enterocytes and immune cells. Moreover, many functions performed by the leukocytes, such as cell division capacity, antibody production, and phagocytosis, are important during recovery since they help to maintain immunological processes in the muscular tissue. Previous studies in horses and humans showed that Gln concentration levels are reduced during the recovery period (Wanderley et al., 2010; Westermann et al., 2011; Santiago et al., 2014, Peake et al., 2014). However, the results reported in the literature are diverse (Beaunoyer et al., 1991; Wanderley et al., 2010), making it difficult to understand this process. Once Gln has an important function as an energy source for the enterocytes and immune system cells, knowledge about Gln metabolism during and after exercise may be important for the recovery and wellbeing of horses.

The amino acid profile of this study contains not only the period immediately after the completion of the exercise, but also the first four hours of recovery period, showing the metabolic activity of these amino acids in the animal's body during recovery. Evaluation of the supplementation/ nutrition therapies of these athletes is essential because the metabolic needs, as the appropriate way of obtaining energy, are determined by the duration and intensity of exercises in the different species of athletes (Marlin and Nankervis, 2002).

\section{Conclusion}

There was an increase in the plasmatic Ala concentration in all the three groups of horses that were evaluated, but only Vaquejada helper horses showed an increase in Gln concentration. The plasmatic Glu concentration did not change in any of the three groups of horses.

\section{References}

Beaunoyer DE, Jackson SG, Gillespie JR, Baker JP. The effect of monosodium glutamate infusion on time to fatigue. Equine Exerc Physiol. 1991;3:209-14.
Bergero D, Assenza A, Schiavone A, Piccione G, Perona G, Coala G. Amino acid concentrations in blood serum of horses performing long lasting low-intensity exercise. J Anim Physiol Anim Nutr (Berl). 2005;89(3-6):146-50.

Coelho CS, Manso HECCC, Manso Filho HC, Ribeiro Filho JD, Abreu JMG, Escodro PB, et al. Escala para avaliação do bem-estar em equídeos atletas. $\mathrm{R}$ Bras Med Equina. 2018;13(75):4-8.

Hanzawa K, Orihara K, Kubo K, Yamanobe A, Ciiraga A, Watanabe S. Changes of plasma amino acid and inorganic ion concentrations with maximum exercises in thoroughbred young horses. J Equine Sci. 1992;3(2):157-62.

Hood DA, Terjung RL. Endurance training alters alanine and glutamine release from muscle during contractions. FEBS Lett. 1994;340(3):287-90.

Hunka MM, Lima LCF, Souza LA, Silva CJFL, Silva ERR, Manso HECCC, et al. Heart rate and velocity in Vaquejada horses during field tests. Comp Exerc Physiol. $2017 ; 13(1): 25-30$.

Lewis GD, Farrell L, Wood MJ, Martinovic M, Arany Z, Rowe GC, et al. Metabolic signatures of exercise in human plasma. Sci Transl Med. 2010;2(33):33ra37.

Manso Filho HC, McKeever KH, Gordon ME, Costa HEC, Lagakos WS, Watford M. Changes in glutamine metabolism indicate a mild catabolic state in the transition mare. J Anim Sci. 2008;86(12):3424-31.

Manso Filho HC, Manso HECCC, Hunka MM, Souza LA, Barros MBS, Coelho CS, et al. Programa de BemEstar para Equídeos: Guia Prático. 2018 [acesso 5 mai 2020]. Disponível em: https://tinyurl.com/yxlhrq3z. DOI: 10.13140/RG.2.2.19463.29606

Marlin D, Nankervis K. Equine exercise physiology. Oxford: Wiley-Blackwell; 2002. 304 p.

Peake JM, Tan SK, Markworth JF, Broadbent JA, Skinner $\mathrm{TL}$, Cameron-Smith D. Metabolic and hormonal responses to isoenergetic high-intensity interval exercise and continuous moderate-intensity exercise. Am J Physiol Endocrinol Metab. 2014;307(7): E539-52. 
Pösö AR, Essén-Gustavsson B, Lindholm A, Persson SGB. Exercise-induced changes in muscle and plasma amino acids levels in the Standardbred horses. In: Persson SGB, Lindholm A, Jeffcott LB (EE.). Equine Exercise Physiology 3. Davis, CA: ICEEP Publications; 1991. P. 202-8.

Santiago TA, Manso HECCC, Abreu JMG, Melo SKM, Manso Filho HC. Blood biomarkers of the horse after field Vaquejada test. Comp Clin Path. 2014;23(3):769-74.

Souza LA, Hunka MM, Nery PCR, Coelho CS, Manso HECCC, Manso Filho HC. The effect of repeated barrel racing on blood biomarkers and physiological parameters in Quarter Horses. Comp Exerc Physiol. 2018;14(1):47-54.

Trottier NL, Nielsen BD, Lang KJ, Ku PK, Schott HC. Equine endurance exercise alters serum branched-chain amino acid and alanine concentrations. Equine Vet J. 2002;34(S34):168-72.

Van Hall G, Saltin B, Wagenmakers AJ. Muscle protein degradation and amino acid metabolism during prolonged knee-extensor exercise in humans. Clin Sci (Lond). 1999;97(5):557-67.
Wanderley EK, Manso Filho HC, Manso HECCC, Santiago TA, McKeever KH. Metabolic changes in four beat gaited horses after field marcha simulation. Equine Vet J. 2010;42(s38):105-9.

Wahren J, Felig P, Hendler R, Ahlborg G. Glucose and amino acid metabolism during recovery after exercise. J Appl Physiol. 1973;34(6):838-45.

Westermann CM, Dorland L, Wijnberg ID, Sain-van der Velden MGM, van Breda E, Barneveld A, et al. Amino acid profile during exercise and training in Standardbreds. Res Vet Sci. 2011;91(1):144-9.

Wolfe RR, Wolfe MH, Nadel ER, Shaw JH. Isotopic determination of amino acid-urea interactions in exercise in humans. J Appl Physiol Respir Environ Exerc Physiol. 1984;56(1):221-9. 